\title{
The genus Anomalon Panzer (Hymenoptera: Ichneumonidae: Anomaloninae) of Iran, with description of a new species
}

\author{
Maryam ZARDOUEI HEYDARI ${ }^{1}$, Ehsan RAKHSHANI ${ }^{2, *}$, Azizollah MOKHTARI ${ }^{3}$ \& \\ Martin SCHWARZ ${ }^{4}$ \\ ${ }^{1,2,3}$ Department of Plant Protection, College of Agriculture, University of Zabol, 98615-538, I.R. Iran. \\ ${ }^{4}$ Eben 21, A-4202 Kirchschlag, Austria. \\ *Corresponding author: rakhshani@uoz.ac.ir \\ 1Email: maryamzardooei@uoz.ac.ir \\ ${ }^{3}$ Email: mokhtari@uoz.ac.ir \\ ${ }^{4}$ Email: schwarz-entomologie@aon.at \\ ${ }^{1}$ urn:lsid:zoobank.org:author:876C1222-A325-4A34-A0E5-06DC7349970F \\ ${ }^{2}$ urn:lsid:zoobank.org:author:86C5B3A2-BE3E-4C3B-B0F1-3B69148E0B9B \\ ${ }^{3}$ urn:lsid:zoobank.org:author:84FD880A-22C6-41C8-ACDC-8B347465BA2A \\ ${ }^{4}$ urn:1sid:zoobank.org:author:27D3A57A-B5CC-47EC-95FD-9B9A31CC2B49
}

\begin{abstract}
The Iranian species of the genus Anomalon Panzer, 1804 (Hymenoptera: Ichneumonidae: Anomaloninae) are reviewed. Four species, Anomalon amseli (Hedwig, 1961), A. chinense (Kokujev, 1915), A. cruentatum (Geoffroy, 1785) and A. narinae Zardouei \& Rakhshani sp. nov., are found to occur in Iran. The female of A. amseli is described for the first time. Anomalon chinense is a new record for Iran. A key to the known Anomalon species of Iran is provided.
\end{abstract}

Keywords. Anomalon, parasitoids, new species, new records, taxonomy, key.

Zardouei Heydari M., Rakhshani E., Mokhtari A. \& Schwarz M. 2020. The genus Anomalon Panzer (Hymenoptera: Ichneumonidae: Anomaloninae) of Iran, with description of a new species. European Journal of Taxonomy 662: 1-19. https://doi.org/10.5852/ejt.2020.662

\section{Introduction}

The Anomaloninae Viereck, 1918 is one of the relatively diverse subfamilies of Ichneumonidae Latreille, 1802, distributed worldwide (Townes 1971; Dasch 1984). Gauld (1976) recognized in this subfamily two tribes, Therionini Viereck, 1918 (= Gravenhorstiini Enderlein, 1912) and Anomalonini Viereck, 1918. The Anomalonini is represented by a single genus Anomalon Panzer, 1804, containing primary parasitoids of Coleoptera Linnaeus, 1758 (Tenebrionidae Latreille, 1802 and Elateridae Leach, 1815) (Townes 1971; Gauld 1976; Gauld \& Mitchell 1977) and Lepidoptera Linnaeus, 1758 (Noctuidae Latreille, 1809 and Tortricidae Latreille, 1803) (Dasch 1984) larvae. According to the most recent monograph on Ichneumonidae (Broad et al. 2018), it remains unresolved as to whether species of Anomalon are parasitoids of either Coleoptera, Lepidoptera or both, i.e., there is no reliable host records 
for the genus. Anomalon is a cosmopolitan genus, but most of the species are known mainly from tropical and subtropical regions (Gauld et al. 1997). About 97 species of Anomalon have been described worldwide, of which 21 species are distributed in the Palaearctic region (Yu et al. 2016).

Up to now, our knowledge on the genus Anomalon in Iran was limited to records of two species, A. amseli (Hedwig, 1961) and A. cruentatum (Geoffroy, 1785) (Masnadi-Yazdinejad \& Jussila 2009; Zarepour et al. 2009; Barahoei et al. 2012, 2014, 2015; Hooshyar et al. 2014). Iran is the second largest country after Saudi Arabia in the Middle East (Abrahamian 1979), which includes a variety of habitats within the wide range of altitudinal zonation ( $-28 \mathrm{~m}$ to $5600 \mathrm{~m}$ above mean sea level), climate types (humid to arid) and temperatures (from $-35^{\circ} \mathrm{C}$ to $70^{\circ} \mathrm{C}$ ), which have led to a high level of biodiversity (Hedge \& Wendelbo 1978). Despite the recent faunistic and taxonomic works on Iranian Ichneumonidae (Shirzadegan et al. 2018; Riedel et al. 2018, 2019a, 2019b; Zardouei Heydari et al. 2019), many parts of the country remains unexplored or poorly studied. This paper is devoted to a taxonomic review of the genus Anomalon in various regions of the country, mainly in the western and eastern areas, to partly fill the gap in our knowledge about occurrence of this genus within these poorly explored areas.

\section{Material and methods}

The specimens of Anomalon examined in this study were collected from 2012 to 2016 in various regions of Iran using Malaise Traps, sweep nets and pan traps The sampling localities are situated in the South East (Kerman, Sistan-o Baluchestan), North East (Khorasan-e Razavi, North Khorasan), East (South Khorasan), Central (Isfahan) and Western (Kermanshah) Provinces of Iran (Fig. 1). Various habitats including agroecosystems, forests and orchards were selected for sampling. The collected specimens were preserved in $75 \%$ ethanol and subsequently treated according to the AXA method (van Achterberg 2009). The dried specimens were point mounted on triangular card and labeled. The external morphology of specimens was studied under a Nikon ${ }^{\circledR}$ SZM645 stereo microscope. Measurements were made with an ocular micrometer mounted on the stereo microscope. Specimens were identified using the keys compiled by Atanasov (1981), Gauld (1978, 1980), Gauld \& Mitchell (1977) and Schnee (2014). Morphological terminology follows Townes (1969) and sculpture terminology follows Harris (1979). Nomenclature systems of Goulet \& Huber (1993) and Gauld (1991) were used for wing veins and

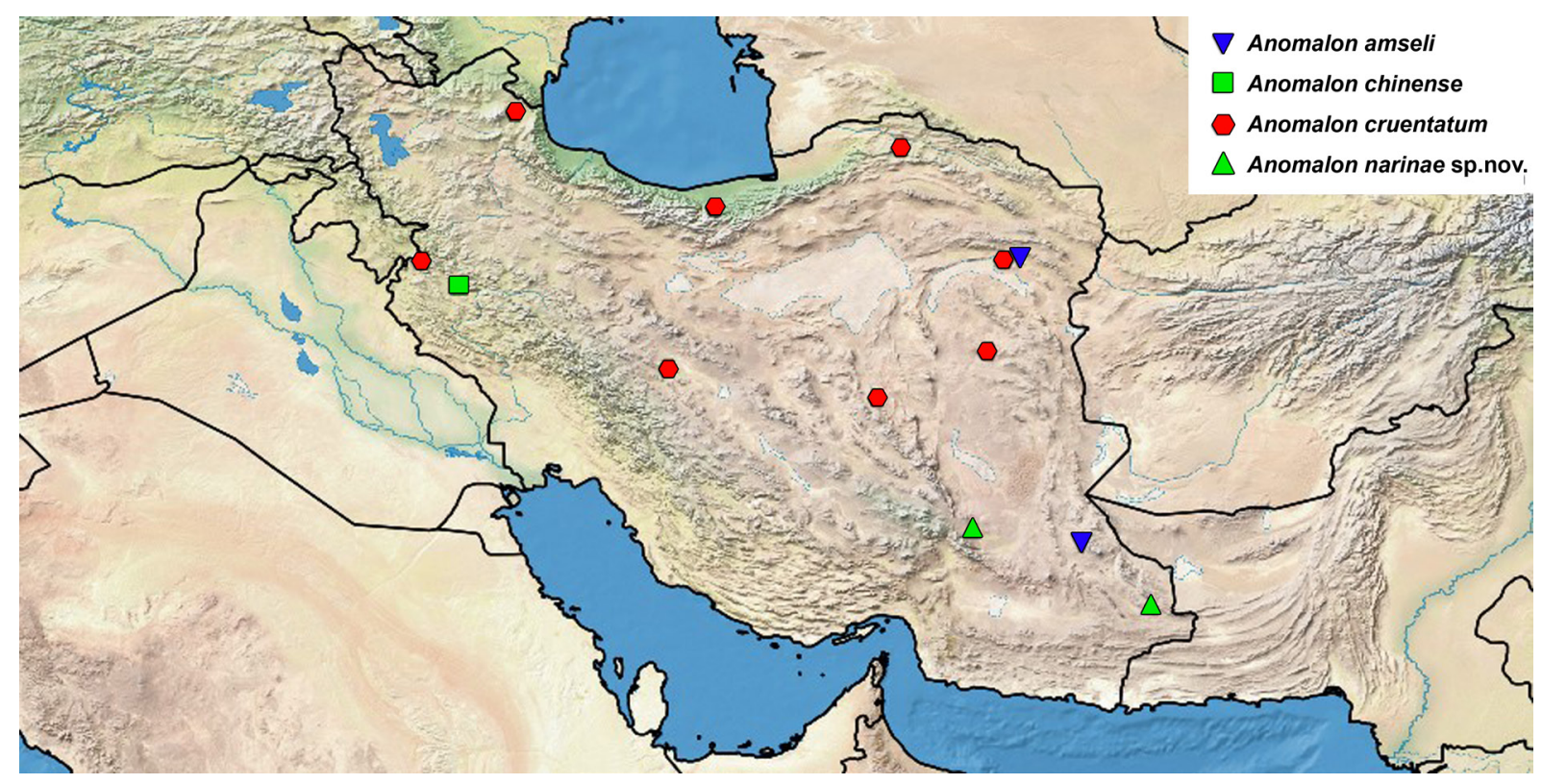

Fig. 1. Distribution map of the known species of Anomalon Panzer, 1804 in Iran. 
wing cells, respectively. Images of the specimens were taken with a digital camera Canon ${ }^{\circledR}$ EOS 700D mounted on a Hund ${ }^{\circledR}$ Wetzlar stereo microscope and processed by Zerene Stacker ver. 1.04 and Adobe ${ }^{\circledR}$ Photoshop CS5. The specimens examined in this study are deposited in the collection of the Department of Plant Protection, University of Zabol, Iran (DPPZ). General distribution of species follows Yu et al. (2016) and is categorized according to the biogeographical zonation proposed by Holzenthal et al. (2015). The distribution map of species of Anomalon in Iran was generated using SimpleMappr (Shorthouse 2010) (Fig. 1).

\section{Results}

\section{Taxonomic account}

Family Ichneumonidae Latreille, 1802

Subfamily Anomaloninae Viereck, 1918

Tribe Anomalonini Viereck, 1918

Genus Anomalon Panzer, 1804

\section{Diagnosis}

The species of Anomalon can easily be recognized from other Anomaloninae by the combination of the following morphological features: notaulus indistinct, represented by a rugose area; fore wing with $r-m$ joining $2 / M$ distal to $2 m-c u$; hind wing with distal abscissa of $2 / C u$ entirely absent; epipleurum of third metasomal tergite separated by a crease just below the spiracle; mid tibia with a single apical spur.

Anomalon amseli (Hedwig, 1961)

Figs $2-3$

Microcremastus amseli Hedwig, 1961: 292.

\section{Material examined}

IRAN - Sistan-o Baluchestan Province • 1 क; Khash, Chah-nali; 28 46'41" N, 6046'44" E; $2124 \mathrm{~m}$ a.s.l.; 16 May 2012; H. Barahoei leg.; swept on Medicago sativa; DPPZ.

\section{Description}

\section{Female}

Size. Body length $8.5 \mathrm{~mm}$, fore wing $4.5 \mathrm{~mm}$, ovipositor sheath $1.8 \mathrm{~mm}$ (Fig. 3B).

Colour. Body generally brown (Fig. 3B); inner eye orbits, stripes between median and lateral lobes of mesoscutum, scutellum apically, propodeum lateroapically, fore leg, hind coxa and hind femur apically, hind tibia basally, first metasomal tergite anteriorly and posteriorly, and narrow stripe on posterior margin of second metasomal tergite yellowish.

HEAD. Antenna with 18 flagellomeres. Occipital carina dorsomedially narrowly interrupted, its lower part not sinuate and reaching base of mandible. Ocelli very small, diameter of lateral ocellus shorter than distance between lateral ocellus and margin of eye (Fig. 2A). Frons slightly concave, smooth and polished, without median vertical ridge. Clypeus weakly and very sparsely punctate, its width $3.0 \times$ its height, its apical margin rounded and with a pair of distinct lateromedian teeth, quite distant from each other. Inner eye orbits weakly convergent ventrally. Malar space about $0.3 \times$ basal mandibular width. Upper tooth of mandible longer than lower tooth. Face elongate, distance between eyes across clypeal fovea about $1.7 \times$ as wide as its length from antennal insertion to median apex of clypeal margin (Fig. 2B). Temple wide, not constricted behind eyes, about $0.9 \times$ as wide as compound eye in lateral view (Fig. 2C). 

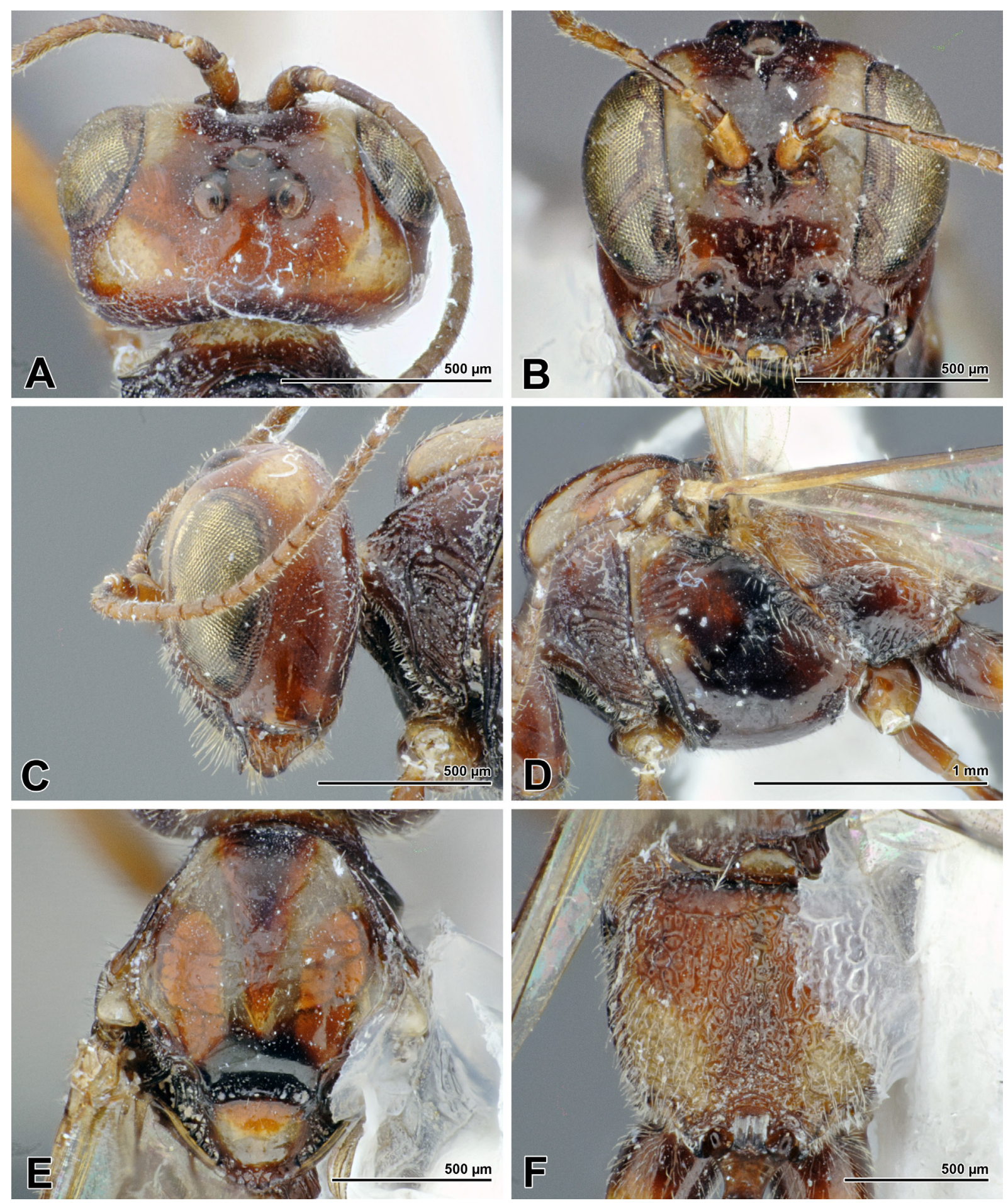

Fig. 2. Anomalon amseli (Hedwig, 1961), + , DPPZ. A. Head, dorsal view. B. Head, frontal view. C. Head, lateral view. D. Mesosoma, lateral view. E. Mesoscutum, dorsal view. F. Propodeum, dorsal view. 
Mesosoma. Pronotum striate, with small impunctate area behind epomia (Fig. 2D). Epomia weak, not reaching dorsal pronotal margin. Mesopleuron polished and impunctate. Epicnemal carina at level of sternaulus not broken (without branch to lower posterior corner of pronotum). Metapleuron polished and impunctate centrally. Mesoscutum polished (Fig. 2E). Scutellum polished. Propodeum reticulaterugose (Fig. 2F). Fore wing with $r-r s$ weakly curved near pterostigma. Marginal cell about as long as its distance from end of wing (Fig. 3A).
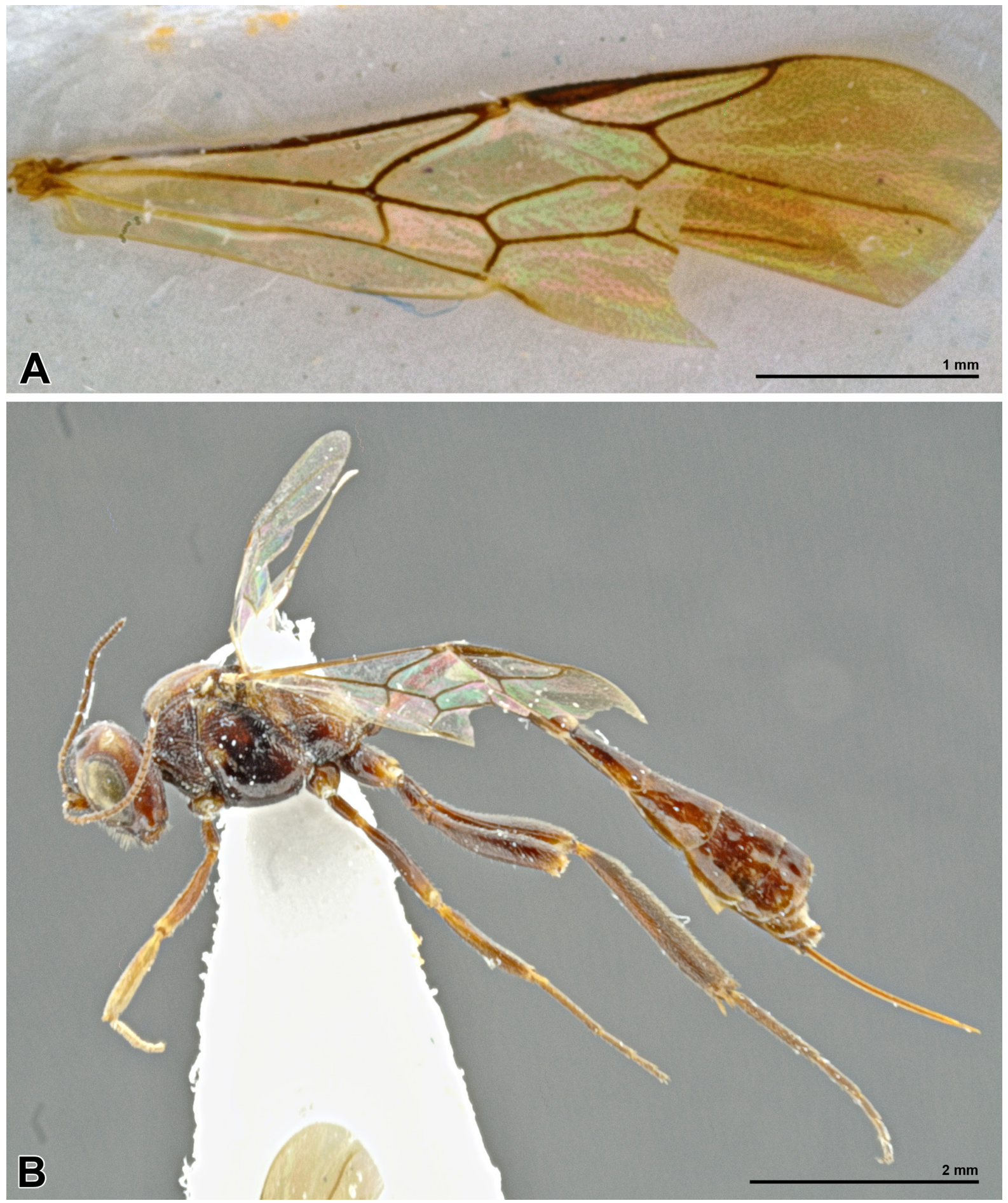

Fig. 3. Anomalon amseli (Hedwig, 1961), , DPPZ. A. Fore wing. B. Habitus, lateral view. 
Metasoma. First tergite $0.8 \times$ as long as second tergite. Second tergite $1.6 \times$ as long as third tergite. Sclerotized part of first sternite extending to the posterior third of the segment. Postpetiole very weakly convex. Spiracle circular, very small. Ovipositor weakly up-curved, with distinct subapical notch. Ovipositor sheath about $1.6 \times$ as long as hind tibia.

\section{General distribution}

Palaearctic: Iran, Afghanistan.

\section{Distribution in Iran}

Khorasan-e Razavi (Masnadi-Yazdinejad \& Jussila 2009) and Sistan-o Baluchestan Provinces (present study).

Anomalon chinense (Kokujev, 1915)

Figs 4-5

Nototrachys chinensis Kokujev, 1915: 536.

\section{Material examined}

IRAN - Kermanshah Province • 1 क; Ghazanchi; 34²7'53" N, 4700'38" E; 1303 m a.s.1.; 2-16 Oct. 2016; M. Zardouei Heydari leg.; Malaise Trap in garden; DPPZ • 3 q $O$; Harsin; $34^{\circ} 19^{\prime} 07^{\prime \prime}$ N, $47^{\circ} 26^{\prime} 13^{\prime \prime}$ E; 1324 m a.s.1.; 1 Aug.-14 Sep. 2016; M. Zardouei Heydari leg.; Malaise Trap in orchard no 2; DPPZ.

\section{Description}

\section{Female}

SizE. Body length 9.0-9.5 mm, fore wing 4.0-4.3 mm, ovipositor sheath 2.4-2.6 mm (Fig. 5B).

Colour. Body yellow; flagellomeres, mesosternum, anterior margin of metapleuron, mandibular teeth, hind trochanter and trochantellus black. Clypeus, first flagellomere of antenna, median and lateral lobes of mesoscutum, two spots on propodeum, base of hind coxa, hind femur, hind tibia and hind tarsus yellowish-brown. Frontal orbit pink. First and second metasomal tergites anteriorly brownish with narrow yellowish band on posterior margins. Third tergite brownish, tergites 4-7 brownish anteriorly and yellowish on posterior margins (Fig. 5B).

HEAD. Antenna with 22-24 flagellomeres. Ocelli small, diameter of lateral ocellus shorter than distance between lateral ocellus and margin of the eye (Fig. 4A). Frons not rugose, with distinct median vertical ridge, long transverse striae beside median vertical ridge. Clypeus width $2.0 \times$ its height, with a pair of rather small lateromedian apical teeth that are very close together. Inner eye orbits convergent ventrally. Lower part of face not elongate, width between eyes across clypeal suture about $1.2 \times$ length from antennal insertion to median apex of clypeal margin (Fig. 4B). Temple not swollen in middle, constricted behind eyes, about $0.53 \times$ as wide as compound eye in lateral view (Fig. 4C).

Mesosoma. Pronotum with large impunctate area behind epomia. Epomia strong, upper end of epomia reaching dorsal pronotal margin. Mesopleuron punctate (Fig. 4D). Epicnemial carina not broken at level of sternaulus (without branch to lower posterior corner of pronotum). Metapleuron rugose. Mesoscutum rugose on median lobe and anterior part of lateral lobes, with punctures on posterior area of lateral lobes (Fig. 4E). Scutellum rugose. Propodeum reticulate-rugose (Fig. 4F). Fore wing with $r$-rs weakly curved near pterostigma. Marginal cell length about $2.0 \times$ its distance from end of wing (Fig. 5A).

Metasoma. First tergite $0.9 \times$ as long as second tergite. Second tergite $1.3 \times$ as long as third tergite. Sclerotized part of first sternite extending to posterior third of segment. Postpetiole convex. Spiracle 
circular, small. Ovipositor weakly down-curved, with distinct subapical notch. Ovipositor sheath about $1.1 \times$ as long as hind tibia.
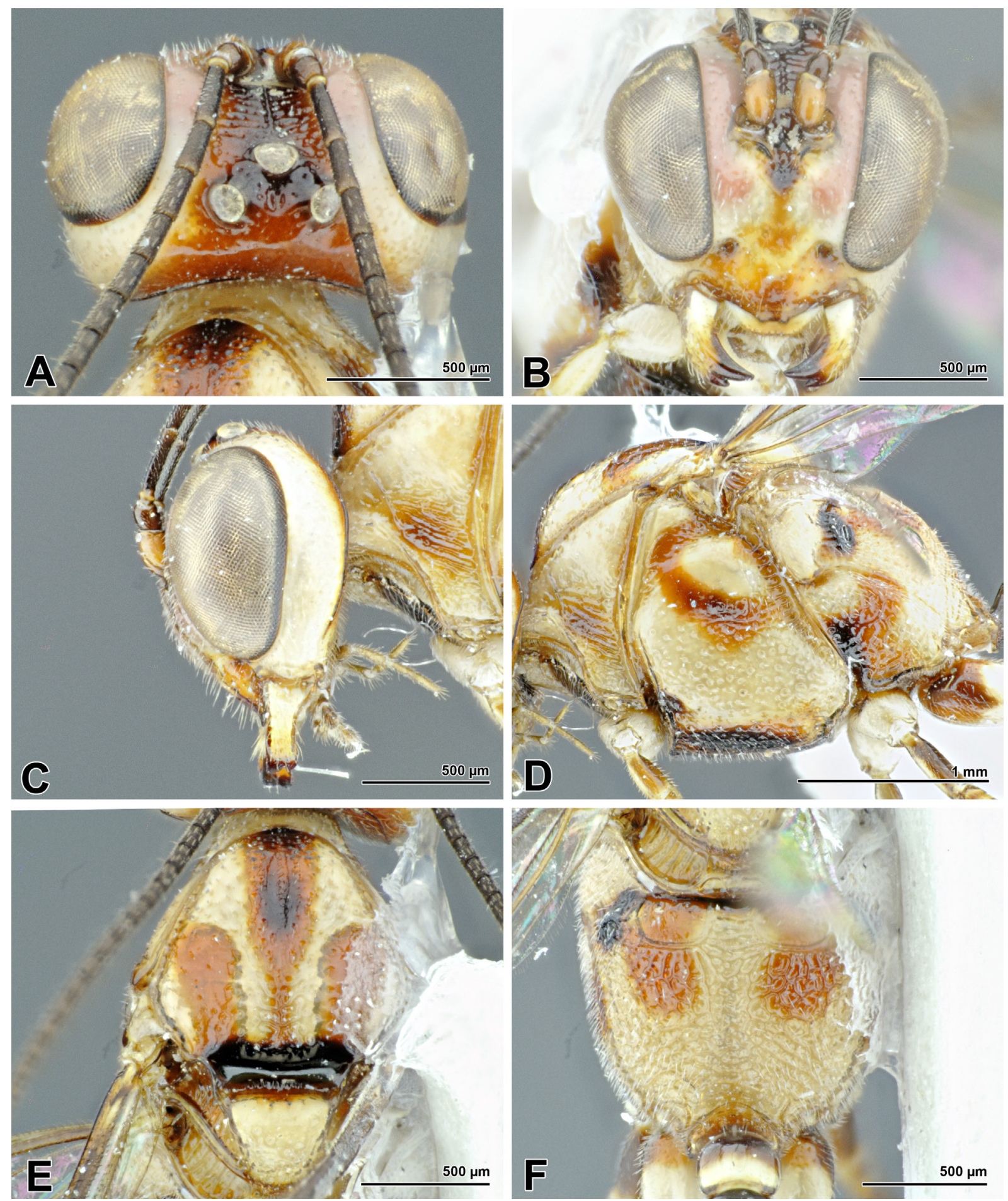

Fig. 4. Anomalon chinense (Kokujev, 1915), , DPPZ. A. Head, dorsal view. B. Head, frontal view. C. Head, lateral view. D. Mesosoma, lateral view. E. Mesoscutum, dorsal view. F. Propodeum, dorsal view. 


\section{Distribution}

Palaearctic (China, Turkmenistan, Iran [new record], Israel).

\section{Distribution in Iran}

Kermanshah Province (present study).
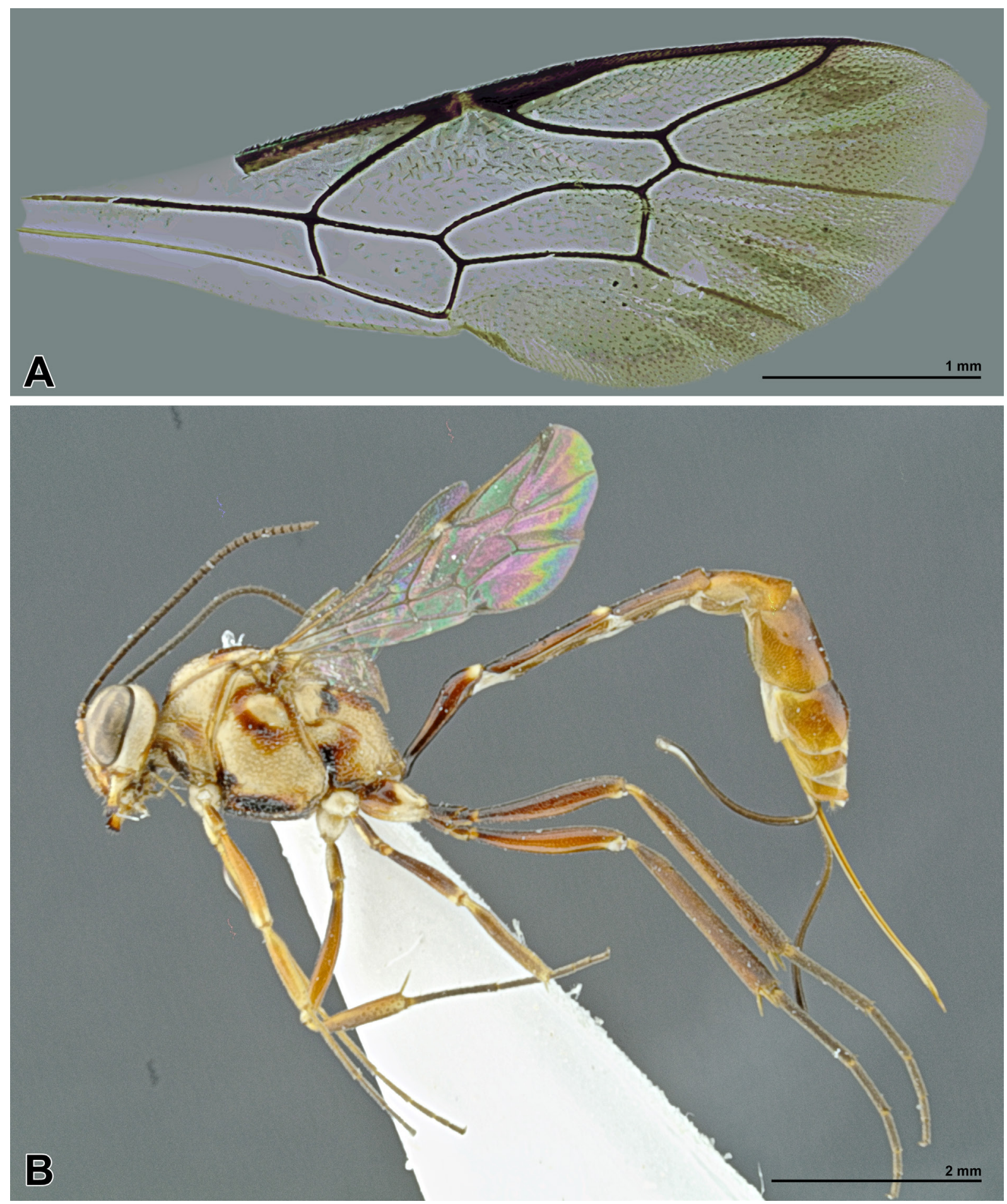

Fig. 5. Anomalon chinense (Kokujev, 1915),, , DPPZ. A. Fore wing. B. Habitus, lateral view. 
Anomalon cruentatum (Geoffroy, 1785)

Figs $6-7$

Ichneumon cruentatus Geoffroy, 1785: 418.

\section{Material examined}

IRAN - Kermanshah Province • 4 o $O$; Ghazanchi; 3426'24" N, 4700'09" E; 1304 m a.s.1.; 14 28 May 2015; M. Zardouei Heydari leg.; Malaise Trap in farm no 3; DPPZ • 2 क ; Bayangan, Dodan; 3500'44" N, 46²'27" E; 954 m a.s.1.; 14-28 May 2015; M. Zardouei Heydari leg.; Malaise Trap

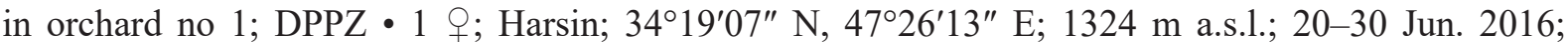
M. Zardouei Heydari leg.; Malaise Trap in orchard no 1; DPPZ • 1 क ; same collecting data as for preceding; 5-19 Jul. 2016; DPPZ 17 q 9 ; same collecting data as for preceding; 10-24 Aug. 2016; DPPZ 11 Q $\bigcirc$; same collecting data as for preceding; 28 Aug.-11 Sep. 2016; DPPZ 1 ○; Bayangan, Dodan; 3500'26" N, 46² 12'51" E; 967 m a.s.1.; 1-15 Jun. 2015; M. Zardouei Heydari leg.; Malaise Trap in orchard no 2; DPPZ $\bullet 7$ 9 \% ; same collecting data as for preceding; 22 Jul.-6 Aug. 2016; DPPZ - 5 우; same collecting data as for preceding; 10-24 Aug. 2016; DPPZ • 1 ; Sahneh; 34 $28^{\prime} 36^{\prime \prime} \mathrm{N}$, 47³5'39" E; 1302 m a.s.l.; 20 Jun.-4 Jul. 2016; M. Zardouei Heydari leg.; Malaise Trap; DPPZ • 3 q ; same collecting data as for preceding; 22 Jul. -6 Aug. 2016; DPPZ $\bullet 2$ q $q$; same collecting data as for preceding; 22 Aug. -6 Sep. 2016; DPPZ $\bullet 2$ o 0 ; same collecting data as for preceding; 28 Aug. -12 Sep. 2016; DPPZ • 5 क; same collecting data as for preceding; 22 Jul.-6 Aug. 2016; Malaise Trap in orchard

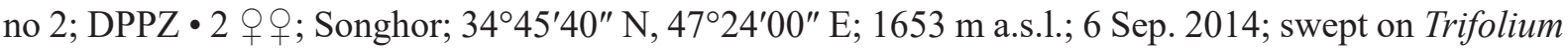
resupinatum; DPPZ $\bullet 1$ क; same collecting data as for preceding; 18 Aug. 2013; Z. Sharifi leg.; swept on Onobrychis altissima; DPPZ • 1 q; same collecting data as for preceding; 29 Aug. 2013; swept on

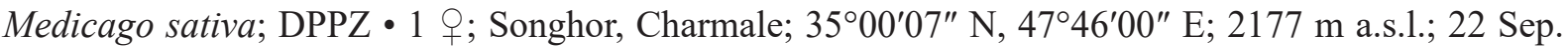
2013; Z. Sharifi leg.; swept on Trifolium resupinatum; DPPZ. - North Khorasan Province - 1 \%; Qale-Khan; 37³0'39" N, 56 46'18" E; 833 m a.s.1.; 11 Jul. 2014; Z. Rahmani leg.; swept on Medicago sativa; DPPZ 4 우; same collecting data as for preceding; 19 Aug. 2014; swept on weeds; DPPZ • 2 우; same collecting data as for preceding; 3 May 2014; swept on Medicago sativa; DPPZ 1 q; same collecting data as for preceding; 17 Jun. 2013; swept on Medicago sativa; DPPZ • 1 \%; same collecting data as for preceding; 2 Jul. 2014; swept on Medicago sativa; DPPZ • 1 우 ; same collecting data as for preceding; 16 Aug. 2013; swept on Medicago sativa; DPPZ • 1 \%; same collecting data as for preceding; 3 Aug. 2014; swept on Medicago sativa; DPPZ 1 ค; same collecting data as for preceding; 19 Aug.

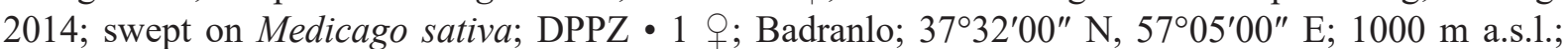
3-17 Aug. 2015; DPPZ. - South Khorasan Province • 1 o; Giuk, Mazar; 3247'45" N, 5907'28" E; 1917 m a.s.l.; 6-20 Aug. 2016; B. Motamedinia leg.; Malaise Trap; DPPZ • 1 q; same collecting data as for preceding; 25 Aug.-8 Sep. 2016; DPPZ • 7 9 우 ; same collecting data as for preceding; 27 Aug.11 Sep. 2016; DPPZ • 8 우; same collecting data as for preceding; 5-19 Sep. 2016; DPPZ • 8 우;

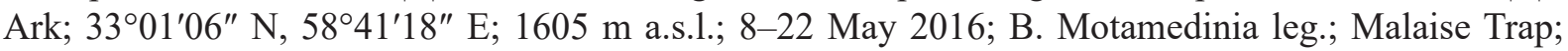
DPPZ • 1 क; Felark; 3310'60" N, 59²2'17" E; 1914 m a.s.1.; 1-15 May 2016; B. Motamedinia leg.; Malaise Trap; DPPZ • 2 q ; same collecting data as for preceding; 7-21 Aug. 2016; DPPZ • 3 우; same collecting data as for preceding; 27 Aug. -11 Sep. 2016; DPPZ $\bullet 1$; ; same collecting data as for preceding; 23 Sep.-7 Oct. 2016; DPPZ. - Khorasan-e Razavi Province • 1 P ; Torghabeh; $36^{\circ} 35^{\prime} 48^{\prime \prime}$ N, 59 $12^{\prime} 58^{\prime \prime}$ E; 1297 m a.s.1.; 12-26 Jun. 2016; B. Motamedinia leg.; Malaise Trap; DPPZ • 1 q; Sabzevar;

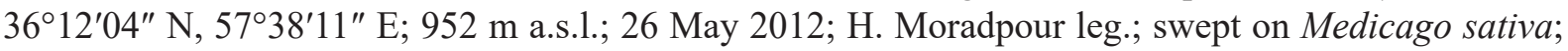
DPPZ • 2 우; Bajestan; 34³1'29" N, 58 10'33" E; 1232 m a.s.1.; 28 Apr. 2013; H. Moradpour leg.; swept on Medicago sativa; DPPZ 2 o $9+$; same collecting data as for preceding; 8 Sep. 2013; DPPZ • 2 + $\odot$; same collecting data as for preceding; 3 Aug. 2014; DPPZ. - Isfahan Province 2 o $\circ$; Nazhvan; $32^{\circ} 38^{\prime} 19^{\prime \prime}$ N, 51 ${ }^{\circ} 38^{\prime} 08^{\prime \prime}$ E; 1579 m a.s.l.; 27 Jun. 2013; E. Nader leg.; swept on Medicago sativa; DPPZ - 3 q 9 ; same collecting data as for preceding; 16 Oct. 2013; DPPZ • 2 q ; same collecting data as for preceding; 27 Oct. 2012; DPPZ. 

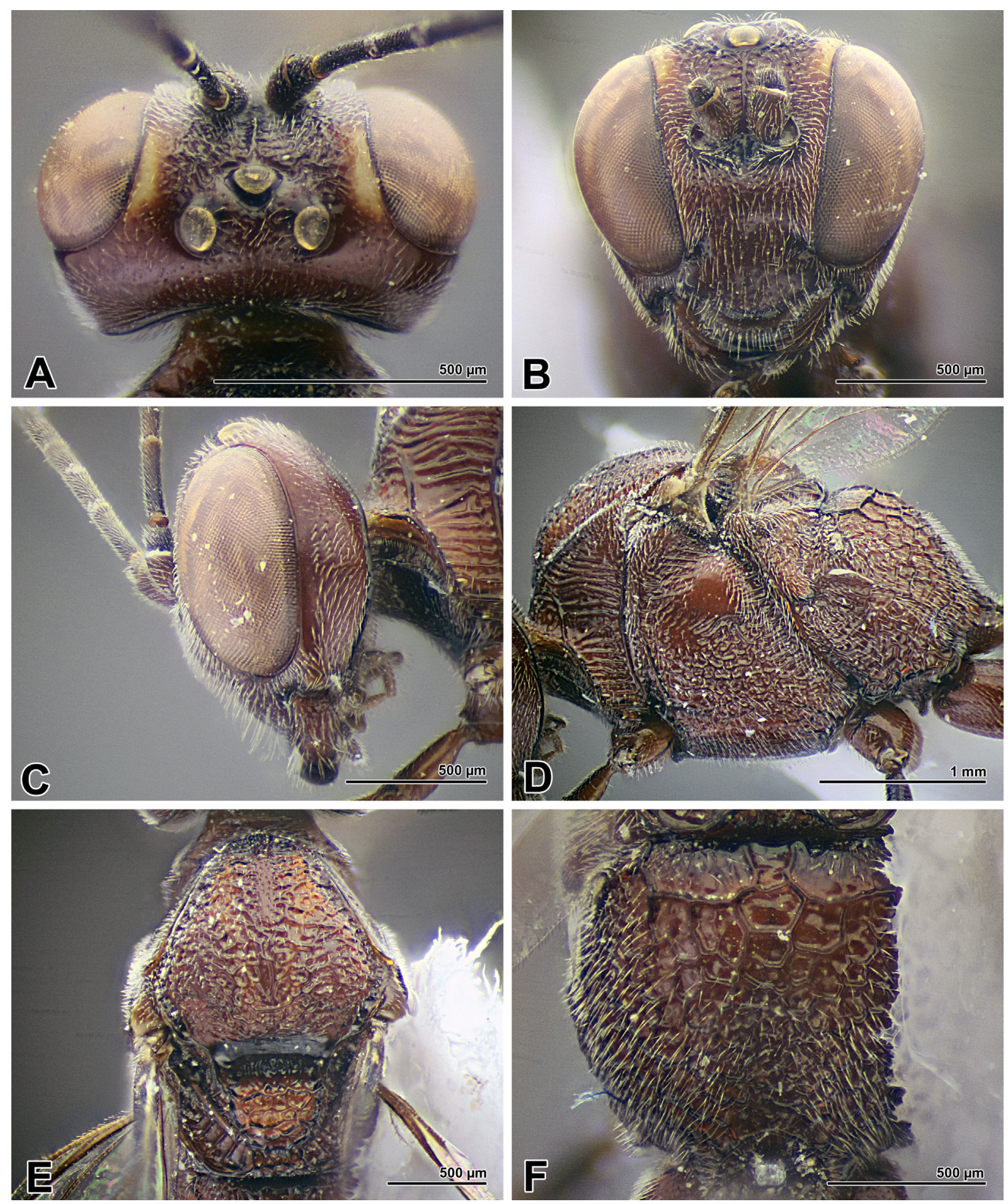

Fig. 6. Anomalon cruentatum (Geoffroy, 1785),, , DPPZ. A. Head, dorsal view. B. Head, frontal view. C. Head, lateral view. D. Mesosoma, lateral view. E. Mesoscutum, dorsal view. F. Propodeum, dorsal view. 


\section{Description}

\section{Female}

SizE. Body length 6.0-11.5 mm, fore wing 3.0-5.5 mm, ovipositor sheath 1.3-2.3 mm (Fig. 7B).

Colour. Body brown; vertical orbit, stripes between median and lateral lobes of mesoscutum, scutellum, fore leg, middle femur apically, middle tibia basally and apically, first metasomal tergite in anterior $2 / 3$ often yellowish. Tergites 2-7 black; tergite 7 often with narrow triangular reddish yellow pattern on posterior margin (Fig. 7B).

HEAD. Antenna with 23-27 flagellomeres. Ocelli small, diameter of lateral ocellus shorter than distance between lateral ocellus and margin of the eye (Fig. 6A). Frons rugose with distinct median vertical ridge, with transverse striae beside vertical ridge. Clypeus width $1.6 \times$ its height, without pair of lateromedian apical teeth. Inner eye orbits convergent ventrally. Lower part of face not elongate, width between eyes across clypeal suture about $1.3 \times$ length from antennal insertion to apex of clypeal margin medially (Fig. 6B). Temple weakly swollen in middle, constricted behind eyes, about $0.66 \times$ as wide as compound eye in lateral view (Fig. 6C).

Mesosoma. Pronotum without impunctate area behind epomia. Epomia strong, upper end of epomia reaching dorsal pronotal margin. Mesopleuron rugose (Fig. 6D). Epicnemial carina broken at level of sternaulus (with branch to lower posterior corner of pronotum). Metapleuron rugose. Mesoscutum rugose (Fig. 6E). Scutellum rugose. Propodeum reticulate-rugose (Fig. 6F). Fore wing with $r$ - $r s$ weakly curved near pterostigma. Marginal cell length about $2.0 \times$ its distance from end of wing (Fig. 7A).

Metasoma. First tergite $0.9 \times$ as long as second tergite. Second tergite $1.4 \times$ as long as third tergite. Sclerotized part of first sternite extending to posterior third of segment. Postpetiole convex. Spiracle circular, small. Ovipositor weakly down-curved, with distinct subapical notch. Ovipositor sheath about $1.2 \times$ as long as hind tibia.

\section{Variation}

Mesosoma mainly black or brown with large black spot on the middle of mesopleuron.

\section{General distribution}

Afrotropical, Oriental and Palaearctic regions.

\section{Distribution in Iran}

Ardabil (Masnadi-Yazdinejad \& Jussila 2009), Isfahan (Barahoei et al. 2015; present study), Korasan-e Razavi (Barahoei et al. 2014; present study), Mazandaran (Hooshyar et al. 2014), Sistan-o Baluchestan (Barahoei et al. 2012), Kermanshah, North Khorasan, South Khorasan (present study) and Yazd Provinces (Zarepour et al. 2009).

Anomalon narinae Zardouei \& Rakhshani sp. nov. urn:1sid:zoobank.org:act:DFB6B559-EB18-49DD-A8B6-B3D15DCF5C6F

Figs $8-9$

\section{Diagnosis}

This species is morphologically similar to Anomalon chinense, but is distinguished by the following characters: 1) the diameter of the lateral ocellus is equal to the distance between the lateral ocellus and the margin of the eye in A. narinae sp. nov. (about $0.8 \times$ in $A$. chinense); 2 ) the mesopleuron is rugose and densely setose in $A$. narinae sp. nov. (punctate, with very sparse setae in $A$. chinense); 3 ) fore wing 

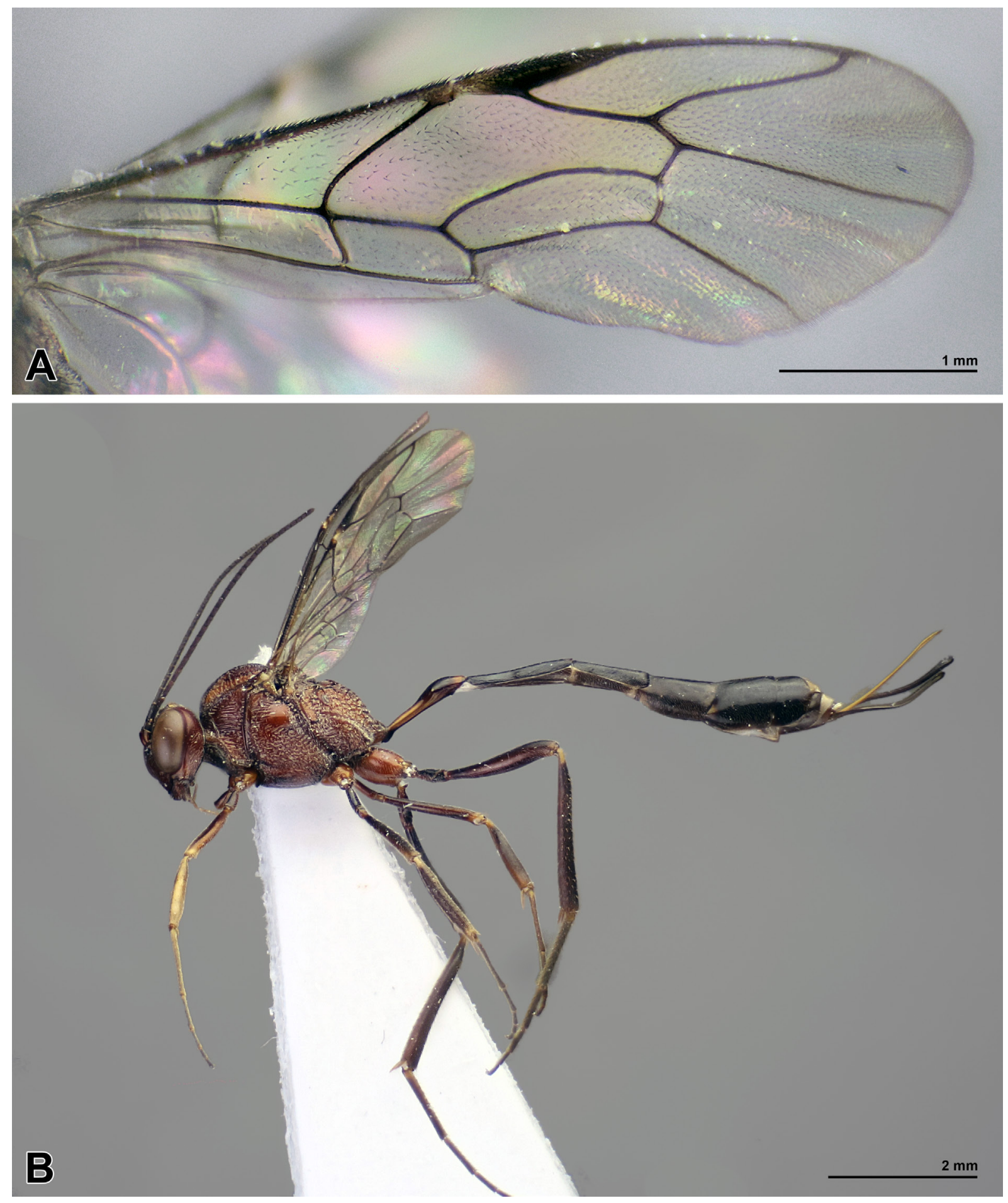

Fig. 7. Anomalon cruentatum (Geoffroy, 1785), , , DPPZ. A. Fore wing. B. Habitus, lateral view. 
$r$-rs vein in A. chinense is weakly curved near the pterostigma, while it is strongly curved in A. chinense; 4) the ovipositor sheath is $0.8 \times$ as long as the hind tibia in $A$. narinae sp. nov. $(1.1 \times$ in $A$. chinense $)$.

\section{Etymology}

The species is named after the niece of the first author, Narin Zardouei.

\section{Type material}

Holotype

IRAN - Sistan-o Baluchestan Province • $O$; Saravan; 27²5'14" N, 62¹7'33" E; 1190 m a.s.1.; 28 Apr.-12 May 2015; M. Khosravi leg.; Pan trap; DPPZ.

\section{Paratypes}

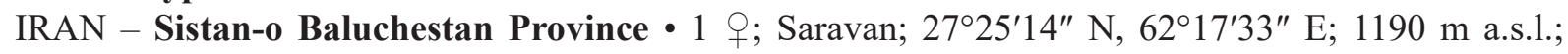
M. Khosravi leg.; 4-18 Sep. 2015; Pan trap; DPPZ • 1 \%; same collecting as for preceding; 21 Apr.3 May 2016; DPPZ • 1 \%; same collecting data as for preceding; 11 Aug. 2016; DPPZ. - Kerman Province • 1 q; Bam; 2905'32" N, 58²0'11" E; 1090 m a.s.1.; 14-28 Jul. 2015; M. Vafaei leg.; Malaise Trap; DPPZ 1 \%; same collecting data as for preceding; 28 Jun. 2015; swept on Medicago sativa;

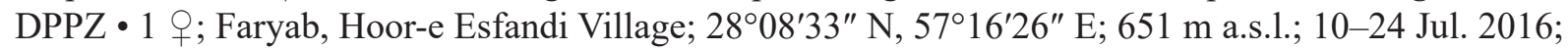
M. Arabzadeh leg.; Malaise Trap; DPPZ $\bullet 1$ q; same collecting data as for preceding; 19 Jul.-3 Aug. 2016; DPPZ 1 क; same collecting data as for preceding; 12 Aug. 2016; swept on weeds; DPPZ.

\section{Description}

\section{Female}

Size. Body length 7.5-10.5 mm, fore wing 3.7-5.0 mm, ovipositor sheath 1.5-1.8 mm (Fig. 9B).

Colour. Body brown; temple, inner eye orbits, lower half of pronotum, upper corner of mesopleuron, stripe between median and lateral lobes of mesoscutum, scutellum, propodeum posteriorly, fore tibia, first tergite on anterior $2 / 3$ and narrow band posteriorly, and second tergite posteriorly yellowish. Tergite 7 with narrow triangular yellowish mark on posterior margin. Wings hyaline, brownish distally (Fig. 9B).

HEAD. Antenna with 22-24 flagellomeres. Occipital carina widely interrupted dorsomedially, its lower part not sinuate, reaching near base of mandible. Ocelli large, diameter of lateral ocellus equal to the distance between lateral ocellus and margin of eye (Fig. 8A). Frons slightly concave, finely punctate, with distinct median vertical ridge, with transverse striae beside median vertical ridge on lower part. Clypeus weakly and very sparsely punctate, its length $2.2 \times$ its width, its apical margin rounded, with a pair of small lateromedian teeth very close to each other. Inner eye orbits convergent ventrally. Malar space about $0.4 \times$ as long as basal mandibular width. Upper tooth of mandible distinctly longer than lower tooth. Face not elongate, width between eyes across clypeal suture about $1.2 \times$ length from antennal insertion to apex of clypeal margin medially (Fig. 8B). Temple strongly constricted behind eyes, about $0.45 \times$ as wide as compound eye in lateral view (Fig. $8 \mathrm{C}$ ).

Mesosoma. Pronotum striate in lower part, with large smooth and impunctate area just behind epomia (Fig. 8D). Epomia strong, its upper end reaching dorsal pronotal margin. Mesopleuron densely rugose. Epicnemial carina almost reaching mid-height of frontal margin of mesopleuron, and at level of sternaulus not broken (without branch to lower posterior corner of pronotum). Speculum polished. Metapleuron densely rugose. Mesoscutum on median lobe rugose posteriorly, median lobe anteriorly and lateral lobe punctate. Scutellum rugose (Fig. 8E). Propodeum reticulate-rugose (Fig. 8F). Fore wing with $r$ - $r s$ very weakly curved near pterostigma. Vein $1 c u-a$ interstitial. Vein $2 / M 1.3 \times$ as long as $r-m$. Marginal cell about twice as long as its distance from end of wing (Fig. 9A). Propodeal spiracle elongate, $2.8 \times$ as long as wide. 

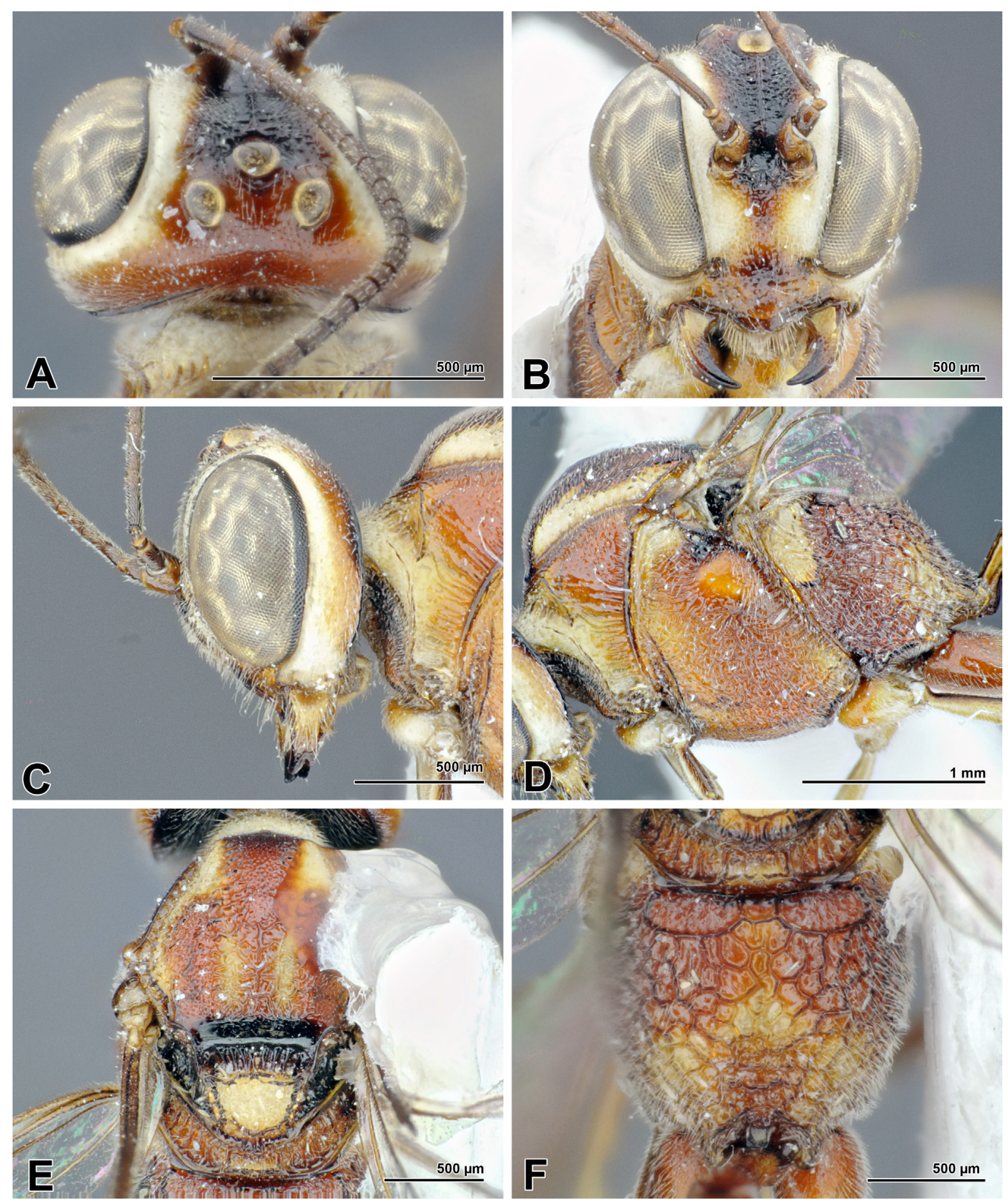

Fig. 8. Anomalon narinae Zardouei \& Rakhshani sp. nov.,, , DPPZ. A. Head, dorsal view. B. Head, frontal view. C. Head, lateral view. D. Mesosoma, lateral view. E. Mesoscutum, dorsal view. F. Propodeum, dorsal view. 
Metasoma. First tergite about $4.0 \times$ as long as apical width and $0.5 \times$ as long as second tergite. Second tergite $5.0 \times$ as long as apical width and $3.0 \times$ as long as third tergite. Sclerotized part of first sternite extending to posterior third of segment. Postpetiole weakly convex, located at posterior 0.4 of first tergite. Spiracle circular, very small. Third tergite $3.0 \times$ as long as apical width. Remaining tergites compressed. Ovipositor sheath about $0.8 \times$ as long as hind tibia.
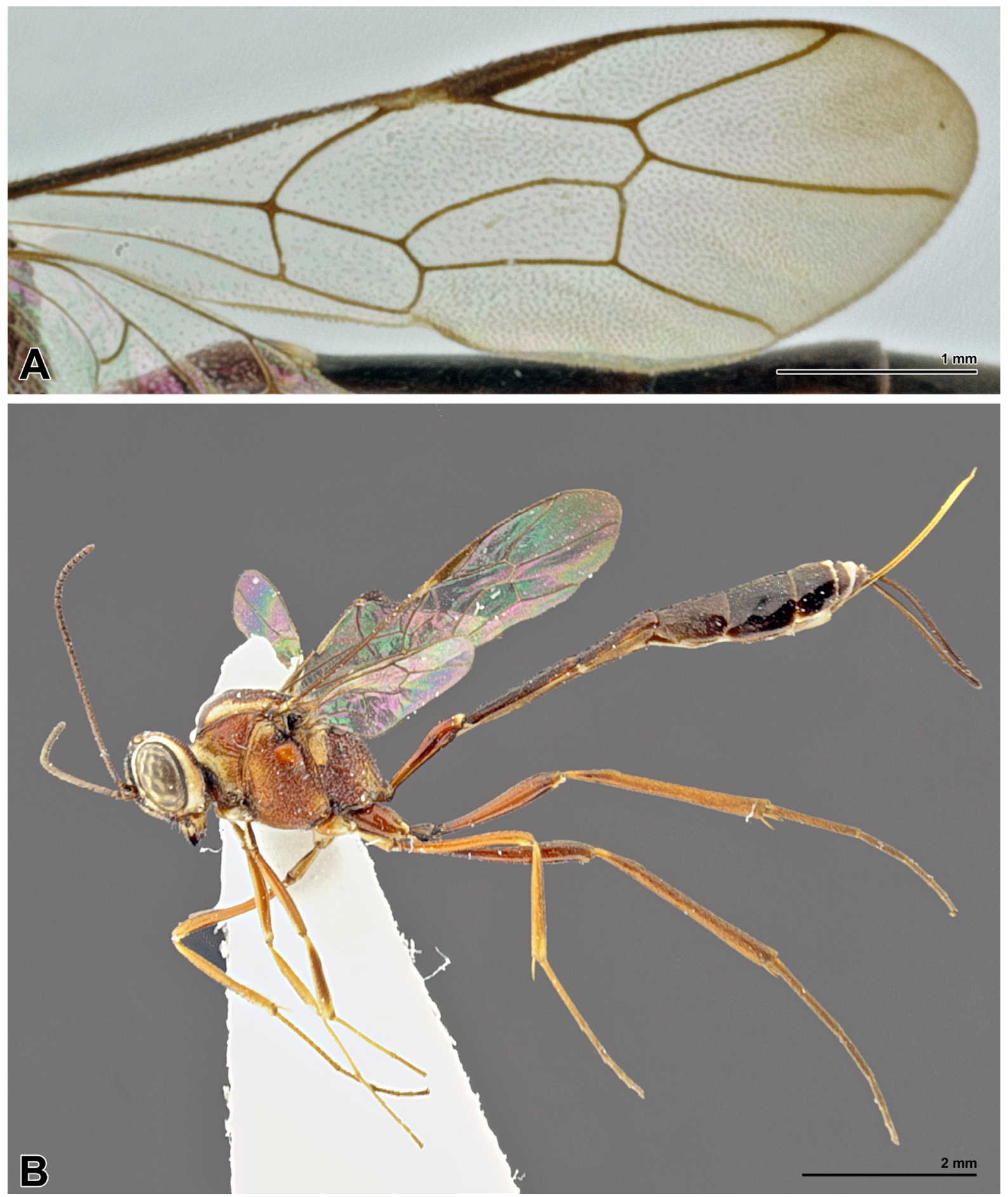

Fig. 9. Anomalon narinae Zardouei \& Rakhshani sp. nov.,, , DPPZ. A. Fore wing. B. Habitus, lateral view. 
Male

Unknown.

\section{General distribution}

Western Palaearctic (Iran).

\section{Distribution in Iran}

Sistan-o Baluchestan and Kerman Provinces.

\section{Key to species of Anomalon occurring in Iran}

1. Marginal cell about $1.0 \times$ as long as its distance from the end of the wing (Fig. 3A); temple not constricted behind eyes, about $0.9 \times$ as wide as the compound eye in lateral view (Fig. 2C)

- Marginal cell about $2.0 \times$ as long as its distance from the end of the wing (Figs 5A, 7A, 9A); temple constricted behind eyes, about $0.45-0.65 \times$ as wide as the compound eye in lateral view (Figs $4 \mathrm{C}$, $6 \mathrm{C}, 8 \mathrm{C})$

2. Clypeus without a pair of lateromedian apical teeth (Fig. 6B); pronotum completely striate and without an impunctate area behind the epomia; epicnemial carina broken at the level of the sternaulus (with a branch to the lower posterior corner of the pronotum) (Fig. 6D)

A. cruentatum (Geoffroy, 1785)

- Clypeus with a pair of lateromedian apical teeth (Figs 4B, 8B); pronotum posteriorly not striate and with an impunctate area behind the epomia; epicnemial carina not broken at the level of the sternaulus (without a branch to the lower posterior corner of the pronotum) (Figs 4D, 8D)

3. Ocelli small, the diameter of a lateral ocellus shorter than the distance between the lateral ocellus and the margin of the eye (Fig. 4A); ovipositor sheath about $1.1 \times$ as long as the hind tibia (Fig. 5B) ...

A. chinense (Kokujev, 1915)

- Ocelli larger, the diameter of a lateral ocellus as long as the distance between the lateral ocellus and the margin of the eye (Fig. 8A); ovipositor sheath about $0.8 \times$ as long as the hind tibia (Fig. 9B) ...

A. narinae Zardouei \& Rakhshani sp. nov.

\section{Discussion}

Previously only two species of Anomalon, A. amseli and A. cruentatum, have been recorded from Iran. Masnadi-Yazdinejad \& Jussila (2009) found A. amseli and A. cruentatum in Khorasan-e Razavi and Ardabil Provinces, respectively. Anomalon cruentatum is widely distributed in several biogeographic ecozones (Afrotropical, Beringian, Boreal Palaearctic, East Palaearctic, South Palaearctic, West Palaearctic). It was recorded as a widely distributed species in Iran (Barahoei et al. 2012; Barahoei et al. 2014; Hooshyar et al. 2014; Barahoei et al. 2015). The record of Anomalon foliator (Fabricius, 1798) from Yazd Province (Zarepour et al. 2009) also refers to A. cruentatum, as a junior synonym. We record species of Anomalon for the first time from at least four provinces in Iran, including Kerman (southeastern), Kermanshah (western province), South Khorasan (eastern province) and North Khorasan (northeastern province).

A single female specimen of $A$. amseli was found on the eastern border of Iran, very close to Afghanistan, where the type specimens (all males) were collected (Hedwig 1961). The previous record of this species from Khorasan-e Razavi (Masnadi-Yazdinejad \& Jussila 2009) was also based on male specimens. Here, we describe the female of $A$. amseli for the first time. This seems to be an uncommon species found at the border of the Western and Southern Palaearctic regions. 
Anomalon chinense is a newly recorded species for the fauna of Iran. It was known from a few countries in the Eastern, Southern and Western Palaearctic regions. We found this species in the western parts of Iran, but it is most probably distributed in the northeastern areas as well, near to Turkmenistan. Anomalon narinae sp. nov. is described from specimens collected from a moderately wide area in southeastern Iran (Kerman and Sistan-o Baluchestan Provinces). Including the results of this research, the number of Anomalon species recorded from Iran increased to four, which represents about $31 \%$ of the known species of Anomaloninae for Iran. Considering the nature of sampling methods, no evidence of host associations was discovered. Indeed, there is no host record for species of Anomalon in Iran.

In conclusion, this survey represents the most detailed one of Anomalon in Iran. Considering the very diverse fauna and flora in Iran (Hedge \& Wendelbo 1978), more undiscovered species of Anomalon are expected to occur in various regions of the country. Further studies, both on their host-parasitoid relationships and their role in natural biological control of their hosts, are also necessary.

\section{Acknowledgments}

This research was supported by grant No. UOZ-GR-9618-6 from the University of Zabol to ER. We would like to express our cordial thanks to Heinz Schnee (Birkenweg 18, 04416 Markleeberg, Germany) for his great help in identification of the specimens, Dr Zoltan Vas (Department of Zoology, Hungarian Natural History Museum, Hymenoptera Collection) and Dr Stefan Schmidt (Staatliche Naturwissenschaftliche Sammlungen Bayerns, Zoologische Staatssammlung, Hymenoptera Collection) for providing the opportunity to study the necessary material. Many thanks also to Hossein Barahoei, Maliheh Khosravi, Hamid Moradpour, Zahra Rahmani, Hossein Ali Derafshan, Mehri Vafaei, Masoumeh Enayatnia, Zohair Sharifi, Behnam Motamedinia and Elham Nader for collecting the core material for this study. Special thanks to Gavin Broad (The Natural History Museum, London) and to Oleksandr Varga (Schmalhausen Institute of Zoology, NAS of Ukraine) for their valuable comments and recommendations on the earlier version of the manuscript.

\section{References}

Abrahamian E. 1979. The causes of the constitutional revolution in Iran. International Journal of Middle East Studies 10 (3): 381-414. https://doi.org/10.1017/S0020743800000179

Atanasov A. 1981. 17. Subfamily Anomaloninae. In: Medvedev G. (ed.) Key to Insects of European Part of USSR. Vol. 3. Hymenoptera. Part 3. Keys to Fauna of USSR 129: 432-451. Nauka, Leningrad.

Barahoei H., Rakhshani E. \& Khajeh N. 2012. A survey on occurrence of Anomaloninae and Ophioninae (Hym., Ichneumonidae) in Sistan-o Baluchestan province, with a new record for fauna of Iran. In: The $17^{\text {th }}$ National and $5^{\text {th }}$ International Conference of Biology of Iran: 167. University of Kerman.

Barahoei H., Rakhshani E., Fathabadi K. \& Moradpour H. 2014. A survey on the fauna of Ichneumonidae (Hymenoptera) of Khorasan Razavi province. Iranian Journal of Animal Biosystematics 10 (2): 145160.

Barahoei H., Nader E. \& Rakhshani E. 2015. A survey on Ichneumonidae of Isfahan province, central Iran. Journal of Crop Protection 4 (2):157-166.

Broad G.R., Shaw M.R. \& Fitton M.G. 2018. Ichneumonid Wasps (Hymenoptera: Ichneumonidae): their Classification and Biology. Handbooks for the Identification of British Insects 7 (12): 1-418. Royal Entomological Society, London.

Dasch C.E. 1984. Ichneumon flies of America north of Mexico: 9. Subfamilies Theriinae and Anomaloninae. Memoirs of the American Entomological Institute 36: 1-610. 
Gauld I.D. 1976. The classification of the Anomaloninae (Hymenoptera: Ichneumonidae). Bulletin of the British Museum (Natural History) (Entomology) 33: 1-135.

Gauld I.D. 1978. A revision of the Anomaloninae (Hymenoptera: Ichneumonidae) of Melanesia. I. The genera Anomalon Panzer to Aphanistes Foerster. Bulletin of Entomological Research 68 (3): 501-519. https://doi.org/10.1017/S0007485300009482

Gauld I.D. 1980. A synopsis of the Anomaloninae (Hymenoptera: Ichneumonidae) of sub-Saharan Africa with special reference to species of potential economic importance. Bulletin of Entomological Research 70 (1): 33-41. https://doi.org/10.1017/S0007485300009743

Gauld I.D. 1991. The Ichneumonidae of Costa Rica. Memoirs of the American Entomological Institute 47: $1-589$.

Gauld I.D. \& Mitchell P. A. 1977. Ichneumonidae. Orthopelmatinae and Anomaloninae. Handbooks for the Identification of British Insects 7 (2): 1-29. Royal Entomological Society, London.

Gauld I.D., Wahl D.B., Bradshaw K., Hanson P. \& Ward S. 1997. The Ichneumonidae of Costa Rica, 2. Memoirs of the American Entomological Institute 57: 1-485.

Geoffroy E.L. 1758. Secundum methodum Geoffroeanam in sectiones, genera \& species distributus: cui addita sunt nomina trivialia \& fere trecentae novae species. In: Fourcroy A.F. (ed.) Entomologia Parisiensis. Sive Catalogus Insectorum quae in Agro Parisiensi reperiuntur. Pars Prima: 1-480. Via et Aedibus Serpentiensis, Paris.

Goulet H. \& Huber J. 1993. Hymenoptera of the World: An Identification Guide to Families. Centre for Land and Biological Resources Research, Ottawa.

Harris R.A. 1979. A glossary of surface sculpturing. Occasional Papers in Entomology 28: 1-31.

Hedge I.C. \& Wendelbo P. 1978. Patterns of distribution and endemism in Iran. Notes from the Royal Botanic Garden Edinburgh 36: 441-464.

Hedwig K. 1961. Ergebnisse der Deutschen Afghanistan - Expedition 1956 der Landessammlungen fur Naturkunde Karlsruhe. Ichneumonidae, Braconidae (Hymenoptera). Beitrage zur Naturkundlichen Forschung in Sudwestdeutschland 19: 291-298.

Holzenthal R.W., Thomson R.E. \& Ríos-Touma B. 2015. Order Trichoptera. In: Thorp J.H. \& Rogers D.C. (eds): Freshwater Invertebrates, Ecology and General Biology $4^{\text {th }}$ Edition Vol. 1: 965-1002. Academic Press, Elsevier, New York. https://doi.org/10.1016/B978-0-12-385026-3.00038-3

Hooshyar H., Vafaei-Shoushtari R. \& Barimani-Varandi H. 2014. Faunistic study of Ichneumon wasps, (Hym., Ichneumonidae) from Mazandaran province, Iran. Journal of Entomological Research 6 (2): 191-202.

Kokujev N.R. 1915. Ichneumonidea (Hym.) a clarissimis V.J. Roborowski et P.K. Kozlov annis 18941895 et 1900-1901 in China, Mongolia et Tibetia lecti 2. Ezhegodnik Zoologicheskago Muzeya [Annales du Musee zoologique. Academie imperiale des Sciences] 19: 535-553.

Masnadi-Yazdinejad A. \& Jussila R. 2009. A contribution to ichneumonid wasps of Iran (Hym.: Ichneumonidae): Anomaloninae, Cremastinae, Ctenopelmatinae, Mesochorinae, Metopiinae and Orthopelmatinae). Applied Entomology and Phytopathology 76 (2): 11-28.

Riedel M., Ameri A., Talebi A.A. \& Ebrahimi E. 2019a. Contribution to the Ichneumonidae (Hymenoptera) of Iran, with descriptions of seven new species. Linzer biologische Beiträge 51:361-390.

Riedel M., Mohammadi-Khoramabadi A. \& Khayrandish M. 2019b. Two new species of Campopleginae (Hymenoptera: Ichneumonidae) from Iran. Zoology in the Middle East 65 (3): 256-260.

https://doi.org/10.1080/09397140.2019.1615751 
Riedel M., Shirzadegan F. \& Talebi A.A. 2018. Two new species of the genus Anisobas Wesmael (Hymenoptera: Ichneumonidae: Ichneumoninae) from Iran and Uzbekistan. Zoology in the Middle East 64: 262-266. https://doi.org/10.1080/09397140.2018.1462597

Schnee H. 2014. Anomaloninae aus Israel und Palästina mit Beschreibung einer neuen Anomalon-Art (Hymenoptera: Ichneumonidae). Entomologische Zeitschrift Schwanfeld 124 (2): 97-107.

Shirzadegan F., Talebi A.A., Riedel M. \& Hajiqanbar H. 2018. Study of the tribe Heresiarchini (Hymenoptera: Ichneumonidae, Ichneumoninae) in northern Iran, with a new record for the Middle East. Journal of Insect Biodiversity and Systematics 4: 113-122.

Shorthouse D.P. 2010. SimpleMappr, an online tool to produce publication-quality point maps. Available from http://www.simplemappr.net [Accessed January 15, 2020]

Townes H.K. 1969. The genera of Ichneumonidae, part 1. Memoirs of the American Entomological Institute 11: 1-300.

Townes H.K. 1971. The genera of Ichneumonidae, part 4. Memoirs of the American Entomological Institute 17: 1-372.

van Achterberg C. 2009. Can Townes type Malaise Traps be improved? Some recent developments. Entomologische Berichten 69 (4): 129-135.

Yu D.S.K., van Achterberg C., Horstmann K. 2016. Taxapad 2016, Ichneumonoidea 2015. Database on flash drive. Nepean, Ontario, Canada.

Zardouei Heydari M., Rakhshani E. \& Mokhtari E. 2019. Occurrence of the genus Erigorgus Förster (Hym., Ichneumonidae, Anomaloninae) in Eastern part of Iran with key to species. Journal of Insect Biodiversity and Systematics 5 (1): 69-78.

Zarepour A.R., Talebi A.A. \& Vafaei-Shoushtari R. 2009. Three new species records of Ichneumonid wasps (Hym., Ichneumonidae) from Yazd, Iran. Journal of Entomological Research 1 (1): 67-77.

Manuscript received: 23 February 2020

Manuscript accepted: 16 April 2020

Published on: 9 June 2020

Topic editors: Gavin Broad and Nesrine Akkari

Desk editor: Radka Rosenbaumová

Printed versions of all papers are also deposited in the libraries of the institutes that are members of the EJT consortium: Muséum national d'histoire naturelle, Paris, France; Meise Botanic Garden, Belgium; Royal Museum for Central Africa, Tervuren, Belgium; Royal Belgian Institute of Natural Sciences, Brussels, Belgium; Natural History Museum of Denmark, Copenhagen, Denmark; Naturalis Biodiversity Center, Leiden, the Netherlands; Museo Nacional de Ciencias Naturales-CSIC, Madrid, Spain; Real Jardín Botánico de Madrid CSIC, Spain; Zoological Research Museum Alexander Koenig, Bonn, Germany; National Museum, Prague, Czech Republic. 